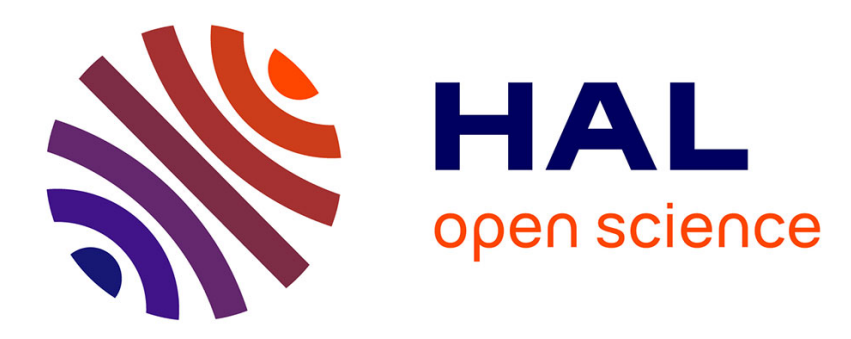

\title{
In Quest of Jean des Murs's Library: An Overview of His Readings and Uses of Manuscripts
}

\author{
Laure Miolo
}

\section{To cite this version:}

Laure Miolo. In Quest of Jean des Murs's Library: An Overview of His Readings and Uses of Manuscripts. Erudition and the Republic of Letters, 2019, 4 (1), pp.13-39. 10.1163/2405506900401002 . hal-02552185

\section{HAL Id: hal-02552185 \\ https://hal.science/hal-02552185}

Submitted on 23 Apr 2020

HAL is a multi-disciplinary open access archive for the deposit and dissemination of scientific research documents, whether they are published or not. The documents may come from teaching and research institutions in France or abroad, or from public or private research centers.
L'archive ouverte pluridisciplinaire HAL, est destinée au dépôt et à la diffusion de documents scientifiques de niveau recherche, publiés ou non, émanant des établissements d'enseignement et de recherche français ou étrangers, des laboratoires publics ou privés. 
In quest of Jean des Murs's library: An overview of his readings and uses of manuscripts

\author{
Laure Miolo
}

Observatoire de Paris, Syrte (UMR 8630)*

\begin{abstract}
Jean des Murs benefited from his connections to the Collège de Sorbonne, of which he was a member at least between 1321-1324 and the end of the 1330s. His annotations in various manuscripts formerly at the Sorbonne show that he took great advantage of the college library. Although few extant manuscripts are certain to have been Jean des Murs's own, the list of book loans in MS El Escorial, Real Biblioteca de San Lorenzo, O.II.10, shows that he had a personal library and that he loaned his books to some of his acquaintances. This article aims at analysing some of the uses Jean des Murs made of the manuscripts available to him as well as reconstructing part of his personal library through the list of loans and extant manuscripts linked to him.
\end{abstract}

\title{
Keywords
}

Jean des Murs; Collège de Sorbonne; medieval libraries; medieval science; University of Paris

\footnotetext{
* This project has received funding from the European Research Council (ERC) under the European Union's Horizon 2020 research and innovation programme (grant agreement No 723085).
} 


\section{Introduction}

During the academic year 1964-65 Guy Beaujouan publicized his discovery, made in 1962, that MS El Escorial, Real Biblioteca de San Lorenzo, O.II.10, contains copious annotations by Jean des Murs, who used it to write down astronomical observations, computations, and practical memoranda. ${ }^{1}$ The identification of Jean's hand in this copy of a collection of astronomical and mathematical texts opened a new path to reconstructing the scholar's biography. Following Beaujouan's study, Lawrence Gushee shed new light on Jean's life, career and milieux, providing important clues for later research. ${ }^{2}$ Jean des Murs's peculiar handwriting allowed Stephen Victor to confirm that MS Paris, Bibliothèque nationale de France (henceforth: $\mathrm{BnF}$ ), lat. 7380, containing the De arte mensurandi was in part copied and annotated by Jean des Murs. ${ }^{3}$

Annotations and private libraries are direct witnesses to reading and research practices and allow us to learn more about individual scholars' working methods, their intellectual networks, and the circulation of texts. Historians of medieval libraries have shown the importance of a close analysis of marginal annotations, and of reconstructing private book

\footnotetext{
${ }^{1}$ Guy Beaujouan, 'Histoire des sciences au Moyen Âge', École Pratique des Hautes Études: Annuaire, IV section (Sciences historiques et philologiques), 97 (1964), 259-62; Beaujouan, 'Observations et calculs astronomiques de Jean de Murs (1321-1344)', in Proceedings of the XIVth International Congress of the History of Science, 4 vols. (Tokyo, 1975), 2:27-30, repr. as chapter 7 in Beaujouan, Par raison des nombres: l'art du calcul et les savoirs scientifiques médiévaux (Aldershot, 1991).

${ }^{2}$ Lawrence Gushee, 'New Sources for the Biography of Johannes de Muris', Journal of American Musicological Society 22 (1969), 2-26, at 5; Gushee, 'Jehan de Murs and his Milieu', in Musik-und die Geschichte der Philosophie und Naturwissenschaften im Mittelalter: Fragen zur Wechselwirkung von 'Musica' und 'Philosophia' im Mittelalter, ed. Frank Hentschel (Leiden, 1998), 339-71, at 346-47.

${ }^{3}$ Stephen Victor, 'Johannes de Muris' Autograph of the De arte mensurandi', Isis 61 (1970), 389-95.
} 
collections. ${ }^{4}$ Three main sources may provide us with clues as to Jean des Murs's reading habits and the content of his own library. First, there are his annotations found in the extant manuscripts of the Collège de Sorbonne. Then, there is the record of book loans in the Escorial MS, which shows that Jean owned a private collection of books and frequently lent individual items to friends or acquaintances. Finally, a handful of extant manuscripts can be shown to have been part of this collection. Taken together, these different strands of evidence allow us to discern with greater precision Jean des Murs's habits as a borrower, reader, an annotator.

\section{Jean des Murs as a member of the Sorbonne}

By the end of the thirteenth century, the Collège de Sorbonne owned one of the richest scientific book collections of Europe, thanks to several large-scale bequests. ${ }^{5}$ Two key

\footnotetext{
${ }^{4}$ See Madeleine Mabille's study of Pierre de Limoges's annotations, which reveals his working methods: Madeleine Mabille, 'Pierre de Limoges et ses méthodes de travail', in Hommages à André Boutemy, ed. Guy Cambier (Brussels, 1976), 244-52. See also Jean-Patrice Boudet, Lire dans le ciel. La Bibliothèque de Simon de Phares, astrologue du XVe siècle (Brussels, 1994). Several recent studies aim at reconstructing private libaries: Claire Angotti, 'Henricus Pistor de Lewis, ses lectures, ses livres et sa bibliothèque: portrait d'un passeur de textes', in Portraits de Maîtres offerts à Olga Weijers, eds. Claire Angotti, Monica Brînzei and Mariken Teeuwen (Porto, 2012), 241-57; Etienne Anheim, 'La bibliothèque personnelle de Pierre Roger/Clément VI', in La vie culturelle, intellectuelle et scientifique à la cour des papes d'Avignon, ed. Jacqueline Hamesse (Turnhout, 2006), 1-48; Anheim, Clément VI au travail: lire, écrire, prêcher au XIVe siècle (Paris, 2014), chapter 5.

${ }^{5}$ For a study of the scientific collection of the early library of the Sorbonne, see Laure Miolo, 'Le fonds scientifique d'un collège de théologie: le cas de la bibliothèque de Sorbonne 1257-1500' (PhD Diss., Université Lumière Lyon 2, 2017), to be published in 2019. For a history of the library of the Sorbonne, from its origins to the great reform of the library (1321) and the elaboration of the fourteenth-century catalogues (1321-1338 and 1321), see Richard Rouse, 'The Early Library of Sorbonne', Scriptorium 21 (1967), 42-71, 227-51. For a study
} 
donations constituted the starting point of the mathematical collection of the Sorbonne:

Gérard d'Abbeville's bequest of more than three-hundred manuscripts in 1272, and the library of Pierre de Limoges (d. 1306), a former fellow of the college ${ }^{6}$ Three quarters of the scientific holdings of both libraries (the loan library and the chained library) came from these donators. As a result of these two important bequests, the Sorbonne could be considered the richest quadrivial library in Paris, one that provided textbooks as well as rare scientific texts.

of several other manuscript collections of the Sorbonne, see Claire Angotti, Gilbert Fournier, Donatella Nebbiai, eds., Les livres des maîtres de Sorbonne: histoire et rayonnement du collège et de ses bibliothèques du XIII ${ }^{e}$ siècle à la Renaissance (Paris, 2017).

${ }^{6}$ The mathematical part of Gérard d'Abbeville's book bequest came from the personal library of Richard de Fournival, on which see Aleksander Birkenmajer, 'La bibliothèque de Richard de Fournival, poète et érudit français du début du XIIIe siècle et son sort ultérieur' [1922], in Etudes d'histoire des sciences et de la philosophie du Moyen Age (Kraków, 1970), 117-210; Richard H. Rouse, 'Manuscripts Belonging to Richard de Fournival', Revue d'histoire des textes 3 (1973), 253-69; Patricia Stirnemann, 'Private Libraries Privately Made', in Medieval Manuscripts, their Makers and Users: A Special Issue of Viator in Honor of Richard and Mary Rouse (Turnhout, 2011), 185-98; Christopher Lucken, 'La Biblionomia de Richard de Fournival: un programme d'enseignement par le livre: le cas du trivium', in Les débuts de l'enseignement universitaire à Paris (1200-1245 environ), eds. Jacques Verger and Olga Weijers (Turnhout, 2013), 89-125. On Pierre de Limoges, who bequeathed more than one-hundred and twenty volumes, see Nicole Bériou, 'La prédication au béguinage de Paris pendant l'année liturgique 1272-1273', Recherches Augustiniennes 13 (1978), 105-229; Bériou, L'Avènement des Maîtres de la Parole: la prédication à Paris au XIIIe siècle, 2 vols. (Paris, 1998), 1:85-86, and passim; Bériou, 'Pierre de Limoges et la fin des temps', Mélanges de l'Ecole française de Rome, 98, no.1 (1986), 65-107. For a biographical and bibliographical synthesis, see Olga Weijers, Le travail intellectuel à la Faculté des Arts de Paris: textes et maitres (c. 1200-1500), vol. 7 (Turnhout, 2007), 196-99. On both scientific libraries, see Miolo, 'Le fonds scientifique', 306-460. 
It is therefore not surprising that Jean des Murs would have chosen to move in this environment between at least 1321-1324 and the end of the 1330s. ${ }^{7}$ The library of the Collège offered him a special place to find all the materials he needed to produce his own work. ${ }^{8}$ It is also likely that the close links between Jean des Murs and other scholars of the Sorbonne, such as Pierre Roger (that is, Pope Clement VI), who summoned him to the curia in Avignon in 1344 , were forged in that context. ${ }^{9}$

Despite the evidence provided by his texts and the manuscripts he annotated, Jean des Murs's presence is not attested in the normative sources of the Collège. References to him in early modern sources must obviously be interpreted with great caution. The main source mentioning Jean des Murs is the Domus et societatis Sorbonice historia written by Mauduison (fl. 1687). This work aims at tracing the Collège's history, including lists of former fellows and their works, in an apologetic manner. Even if this treatise is not reliable, one of Mauduison's merits is to have consulted medieval sources of the Collège in order to establish some of his entries. The entry devoted to Jean des Murs is numbered $79 .{ }^{10} \mathrm{He}$ is said to have

\footnotetext{
${ }^{7}$ On his stays at the Sorbonne, see Gushee, 'Jehan des Murs', 346-47. See also Emmanuel Poulle, 'John of Murs', in Complete Dictionary of Scientific Biography, 27 vols. (Detroit, 2008), 7:128-133.

${ }^{8}$ Given the explicit of his works, he wrote at least the Kalendarium solis et lune, the first version of the Musica speculativa, and the Arbor Boecii during his first stay. The Canones tabularum Alfonsii of 1339 are the latest attestation of Jean's presence at the Sorbonne. See Gushee, 'New Sources', 8. On the Kalendarium solis et lune, see José Chabás and Bernard Goldstein, 'John of Murs Revisited: The Kalendarium Solis et Lune for 1321', Journal for the History of Astronomy 43 (2012), 411-37. See also Philipp Nothaft's contribution in this volume.

${ }^{9}$ Pierre Roger (Clement VI) was provisor of the Sorbonne between 1326 and 1336. See Palémon Glorieux, Aux origines de la Sorbonne, 2 vols. (Paris, 1965-1966), 1:139-40.

${ }^{10}$ MS Paris, Bibliothèque de 1'Arsenal 2021, fol. 376r: '79. Joannes de Muris. Joannes de Muris, in collecta annis 1360, inter socios Sorbonnicos recensatur. De illo in manuscripto 897, in quo continetur Geometria Euclidis, initio scriptum est “pro Joanne de Muris”, ex quo satis colligitur. Eum praecipui mathematicarum disciplinarum fuisse studiosum, itaque de eodem suspicamur inscripsisse epitomem Gesneri: “Joannis de Muris
} 
been identified in the collecta of 1360 . The term collecta here refer to prayers said during an annual meeting in memory of former members. Jean des Murs probably died a decade earlier, so his appearance in the 1360-list would be consistent with the known chronology of his life. Mauduison located his name in one manuscript of the Collège containing Euclid's Elements in Hermann of Carinthia's translation, which is MS Paris, BnF, lat. 16646. Indeed, the note pro J[ohanne] de Muris is written on the first page. ${ }^{11}$ Confronted with this piece of evidence, Mauduison quoted a short bibliographical reference found in Conrad Gessner's Bibliotheca universalis, which only mentioned the Arithmetica speculativa, printed for the first time in Vienna in $1515 .^{12}$

Mauduison's treatise reveals nothing concerning Jean des Murs's status at the Sorbonne. We learn little more from the scattered evidence contained in MS Paris, Bibliothèque de l'Arsenal, 1228, which is a composite volume combining several printed and manuscript sources ranging from the sixteenth to the eighteenth century. It includes a list of fellows classified according to current provisors. 'Julianus de Muris' is mentioned as fellow during the time of Annibal de Ceccano (provisor from 1320 to 1326). ${ }^{13}$ Yet it is precisely during the tenure of Annibal de Ceccano that Jean des Murs stayed at the Sorbonne for the

Arithmetica speculativa libri duo libri duo emendati, et exemplis formis que novis declaratis. Iuo Schoeffer excudit Moguntiae, 1538"”.

${ }^{11}$ On the Elements translated by Hermann of Carinthia, see The Translation of the Elements of Euclid from the Arabic into Latin by Hermann of Carinthia: Books I-VI, ed. Hubert L. L. Busard (Leiden, 1968); Busard, The Translation of the Elements of Euclid from the Arabic into Latin by Hermann of Carinthia: Books VII-XII (Amsterdam, 1977).

${ }^{12}$ Conrad Gessner, Bibliotheca universalis, sive Catalogus omnium scriptorum locupletissimus, in tribus linguis, latina, graeca et hebraica (Zurich, 1545), 444.

${ }^{13}$ MS Paris, Bibliothèque de l'Arsenal, 1228, fol. 345r. The list is reproduced in Alfred Franklin, La Sorbonne: ses origines, sa bibliothèque (Paris, 1875), 15. 
first time. Hence, it would seem that here and elsewhere the lists of MS Paris, Bibliothèque de l'Arsenal, 1228 substitute Julianus for Johannes. Julien des Murs was probably Jean des Murs's relative and had a successful ecclesiastical career at court as well as at the university. Based on his benefices and his career, one may conclude that Julien held a university degree in theology, perhaps a doctorate. ${ }^{14}$

What was Jean des Murs's status within the college? Was he a guest or a fellow? Two entries in the Escorial MS refer explicitly to bursae payments to Gilles d'Abbeville, who was procurator, that is, bursar of the college. ${ }^{15}$ They usually correspond to a long time period, exceeding one year. ${ }^{16}$ In the fourteenth century, a socius was not necessarily a scholar receiving a bursary. Olga Weijers points out that an act of 1312 mentions fellows living in the Collège at their own expense: immorantes in domo bursis propriis. From 1312, the Sorbonne distinguished the socius, member of the Collège, and the bursalis, a fellow with a bursary. In the fifteenth century, the Book of Priors specified that a scholar could benefit either from a societas cum bursis or from a societas sine bursis. Whether they had a grant or not, they remained a fellow of the Collège. The fellow without bursary was required to pay a financial contribution to the Collège, which was named bursa. ${ }^{17}$

The term hospes is less clear. Originally, it referred to guests passing through the Collège who had the right to stay and eat on the Sorbonne common funds for fewer than five

\footnotetext{
${ }^{14}$ On Julien des Murs, see Gushee, 'New sources', 22-24; Gushee, ‘Jehan des Murs', 364-66.

${ }^{15}$ MS El Escorial, Real Biblioteca de San Lorenzo, O.II.10, fol. 1v: 'Bursae de Sorbona quelibet de 5s 6d valent per annum precise 14 lib 6s 9d 3/7 unius d'. Ibid., fol. 8v: 'Ultima die Augusti, solvi omnia scilicet bursas preteritas.'

${ }^{16}$ For a detailed discussion of these payments, see Gushee, 'New sources', 18.

${ }^{17}$ Olga Weijers, 'Le vocabulaire du collège de Sorbonne', in Vocabulaire des collèges universitaires (XIIIe-XVIe siècles), ed. Olga Weijers (Turnhout, 1992), 9-25, repr. in Olga Weijers, ed., Études sur la Faculté des arts dans les universités médiévales: recueil d'articles (Turnhout, 2011), 37-55, at 43-46.
} 
days. However, the fifteenth-century Book of Priors mentions several hospites renting a room in the Collège for a year. It became common practice that after this year they applied for the status of fellow. ${ }^{18}$ Given his extended stays at the Collège and his loan of MS Paris, BnF, lat. 16646, one can assume that Jean des Murs was a socius sine bursis. ${ }^{19}$ However, in order to be a fellow as well as a guest of the Sorbonne, he must have pursued a degree in theology.

\section{Jean des Murs, annotator of Sorbonne manuscripts}

Jean des Murs's status as a member of the Sorbonne gave him access to the library and the right to borrow books from the loan collection. As a matter of fact, his distinctive handwriting can be discerned in some of the Sorbonne's manuscripts and in a medieval library catalogue of the Collège. In 1321, at the time of Jean's first stay, Annibal de Ceccano initiated a largescale reform of the library and its statutes. New catalogues were written for the loan library (1338) as well as for the chained library (1321-1338). ${ }^{20}$ It is worth noting that the main part of the analytical catalogue was produced during Jean des Murs's first stay at the Collège. Indeed, some of the entries related to the quadrivium (Libri quadriviales) are annotated by him. ${ }^{21}$ They include notae consisting of three dots and a descender that served as mnemonic references for localising the chained manuscripts he wanted to consult.

\footnotetext{
${ }^{18}$ Robert Marichal, Le livre des prieurs de Sorbonne (1431-1485) (Paris, 1987), 32, 37-8.

19 The mention of his name in MS Paris, BnF, lat. 16646, and the presence of this manuscript in the loan collection of the Collège indicate that he borrowed it.

${ }^{20}$ Both catalogues are now MS Paris, BnF, n.a.1. 99. See Rouse, 'The Early Library'; Gilbert Fournier, 'Listes, énumérations, inventaires: les sources médiévales et modernes de la bibliothèque du Collège de Sorbonne', Scriptorium 65 (2011), 158-216.

${ }^{21}$ On the Libri quadriviales rubric, see Miolo, 'Le fonds scientifique', 2:1-13.
} 
Next to the item Astronomia Leopoldi, which corresponds to the Compilatio de astrorum scientia of Leopold of Austria, Jean wrote 'which is of little value' (que modicum valet). ${ }^{22}$ This codex was owned by Pierre de Limoges, who referred to it in his annotations, ${ }^{23}$ but it does not seem to be extant. In the same vein he added to the entry for Albumasar's De magnis coniunctionibus a simple nota de coniunctionibus. This treatise was listed with the shelfmark 'P.f', which corresponds to Richard of Fournival's astrological anthology, MS Paris, BnF, lat. $16204 .{ }^{24}$ Finally, several items corresponding to one volume (called 'V.l') share several notae by Jean: the Tractatus de yride et halo demonstrative, now lost, which was an anonymous treatise on the rainbow. Jean's hand added to it de iride. Witelo's treatise De natura demonum, on optical illusions, also received a nota from Jean. This manuscript, which has not survived, was bequeathed by Peter of Limoges and also contained William of St-Cloud's prologue to the Almanach planetarum. ${ }^{25}$

Extant manuscripts from the Sorbonne exhibit several annotations by Jean des Murs. They were either part of the loan library or of the chained library. All these manuscripts contained scientific texts related to the science of the stars, arithmetic, geometry, and music. Among the chained manuscripts consulted and annotated by Jean des Murs in the field of

\footnotetext{
${ }^{22}$ MS Paris, BnF, n.a.1. 99, p. 258. On Leopold of Austria's text, see Joëlle Ducos, 'Astrométéorologie et vulgarisation: le livre VI de Li compilacions de le science des estoilles de Léopold d'Autriche', in Par les mots et par les textes: mélanges de langue, de littérature et d'histoire des sciences offerts à Claude Thomasset (Paris, 2005), 239-56.

${ }^{23}$ MS Paris, BnF, lat. 7320, fol. 46r: 'Item libro Leopoldi 62 folio, pagina I, in margine'.

${ }^{24}$ MS Paris, BnF, n.a.1. 99, p. 257.

${ }^{25}$ On manuscript 'V.l', see Birkenmajer, 'Pierre de Limoges'; Aleksander Birkenmajer, 'Etudes sur Witelo, I', in Etudes d'histoire des sciences en Pologne (Wrocław, 1972), 97-225, at 101-105.
} 
astrology, there is MS Paris, BnF, lat. $16204 .{ }^{26}$ His glosses and notae focus on Albumasar's works. The copy of the Introductorium maius contains several rubrics and notae, for instance a note on the ways to verify judgements, that is, by experience and by observation. ${ }^{27}$ Jean highlights several sources used by Albumasar, among them Aristotle's Peri Hermeneias or Galen's commentary on Hippocrates's Aphorisms. There are also references to the Toledan and Alfonsine Tables. ${ }^{28}$ In the same tract, he quotes a passage from the Astronomia Leopoldi, providing the exact folio number. One can assume that it corresponds to the manuscript chained in the college library, mentioned above. ${ }^{29}$ He applies the same mélange of short explanatory glosses and mnemonic notes to Albumasar's De magnis coniunctionibus. More interesting is the figura celi he completed and annotated in Albumasar's De revolutionibus annorum mundi. ${ }^{30}$ This figura celi corresponds to the horoscope of the vernal equinox of 19

\footnotetext{
${ }^{26}$ For a description of the astrological works contained in this collection, see David Juste, Catalogus Codicum Astrologorum Latinorum, vol. 2, Les manuscrits astrologiques latins conservés à la Bibliothèque nationale de France à Paris (Paris, 2015), 141-44.

${ }^{27}$ MS Paris, BnF, lat. 16204, p. 8: 'hic probantur iudicia astrorum per experimentum et per observationes'. Ibid., p. 71b: 'De iove; De luna; Nota de fortuna planetarum; Nota de venere'. Ibid., p. 73b: 'Nota quanto sciuntur qualitates planetarum'.

${ }^{28}$ Ibid. p. 29b: 'hec sunt verba Aristotelis in primo perymenias'. Ibid., p. 24a: 'Verba Galieni in auforismis'. Ibid., p. 24a: 'per tabulas Alfonsi et Azarchelis'.

${ }^{29}$ Ibid. p. 83: 'id est dum centrum inter longitudinem mediam et oppositionem augis hoc est in parte inferiori epicicli: verbum primum et videlicet hoc Leopoldus fol'. 23 pa[gina] Ia.'

${ }^{30}$ On Albumasar, see Abū Ma $\check{s}$ ar al-Balhī [Albumasar]: Liber introductorii maioris ad scientiam judiciorum astrorum, ed. Richard Lemay, 9 vols. (Naples, 1995-1996); Abū Ma šar on Historical Astrology: The Book of Religions and Dynasties (On the Great Conjunctions), ed. Keiji Yamamoto and Charles Burnett, 2 vols. (Leiden, 2000).
} 
March 656, the date of caliph Uthman's death, and hence of the beginning of Ali's reign. ${ }^{31}$ According to Jean-Patrice Boudet, this year was a key date for Muslim astrologers, especially in the history of Shiism. Jean completed the figura celi and corrected the positions given in the twelfth-century Latin translation of De revolutionibus annorum mundi, which had been elaborated for the latitude of Toledo. At the bottom of the figura celi, Jean corrected and recomputed these data on the basis of the Toledan Tables. ${ }^{32}$

Another astrological chained manuscript previously owned by Pierre de Limoges is MS Paris, BnF, lat. 16206, which contains Haly Abenragel's De iudiciis astrorum. ${ }^{33}$ Jean des Murs annotated especially the part dedicated to the revolutions of the years. His notes are usually short, although he selected various specific passages, introduced by cape written in the margin and followed by a bracket, ending with vide. More interesting is his reference to a Quadripartitum glosatum, including a folio number. Jean is commenting on the part of the text related to planetary conjunctions and oppositions and their political meanings. The conjunction of Jupiter and Mars is supposed to lead to insurrections and wars. Jean focused his gloss on the significance of Mars when the planet was in elevation, mentioning folio 67 of this Quadripartitum glosatum. ${ }^{34}$ This work is simply Ptolemy's Quadripartitum accompanied by Haly Abenrudian's gloss in the translation of Aegidius de Thebaldis, a copy of which was

\footnotetext{
${ }^{31}$ I would like to thank Jean-Patrice Boudet very much for helping me interpret and contextualise this horoscope. See also his contribution in this volume.

${ }^{32}$ MS Paris, BnF, lat. 16204, p. 328: 'Ego feci hanc figuram secundum tabulas equationis .12. domorum ad latitudinem Tholeti'. This note is surrounded by Jean des Murs's re-computation.

${ }^{33}$ On this astrological text see David Pingree, 'Ibn Abî 1-Ridjâl', in Encyclopaedia of Islam, Second Edition Online, eds. P.Bearman, T. Bianquis, C. E. Bosworth, E. van Donzel, W. P. Heinrich (Leiden, 2012) http://dx.doi.org/10.1163/1573-3912_islam_SIM_3051 [accessed 6 March 2018].

${ }^{34}$ MS Paris, BnF, lat. 16206, fol. 214r. Jean specifies in his short note that the planet in elevation is stronger than the planet designated as 'master of the year'.
} 
bequeathed to the Sorbonne by Pierre de Limoges (MS Paris, BnF, lat. 16653). ${ }^{35}$ Jean's interest in Haly Abenragel's treatise can be linked to his judgements on the conjunctions of 1345,1357 and 1365, in which he referred to the De iudiciis astrorum. ${ }^{36}$

As far as astronomy is concerned, his handwriting can be detected in the copy of the Toledan Tables in MS Paris, BnF, lat. 16209, where he added at the very end of the codex some trigonometrical computations on the circle. ${ }^{37}$ Moreover, he probably borrowed another manuscript containing the canons to the Toledan Tables (version $\mathrm{Cb}$ ), the tables themselves, and a collection of texts written by or attributed to Thâbit ibn Qurra. In it, Jean reproduced a conversion table of Christian into Arabic years made by Campanus of Novara, ${ }^{38}$ which is followed by his copy of a table of Arabic months and feasts. ${ }^{39}$

In the field of geometry, although Jean des Murs borrowed the Elements in Hermann of Carinthia's tradition, there is no evidence that he used this version in any of his works. Ghislaine l'Huillier did not identify the tradition followed by Jean in his Quadripartitum numerorum, but she noted that the prologue of the first book includes a quotation of

\footnotetext{
${ }^{35}$ Jean-Patrice Boudet, 'Ptolémée dans l'Occident medieval: roi, savant et philosophe', Micrologus 21 (2013), 193-217.

${ }^{36}$ Jean Patrice Boudet, 'La papauté d'Avignon et l'astrologie', in Fin du monde et signes des temps: visionnaires et prophètes en France méridionale (fin XIII'-début XVe siècle), Cahiers de Fanjeaux 27 (Toulouse, 1992), 25793, here 274-75. On his judgement on the triple conjunction of 1345 , see also Jean-Patrice Boudet's contribution in this volume.

${ }^{37}$ MS Paris, BnF, lat. 16209, fol. 41v.

${ }^{38}$ Fritz S. Pedersen, The Toledan Tables: A Review of the Manuscripts and the Textual Versions with an Edition, 4 vols. (Copenhagen, 2002), 919-20.

${ }^{39}$ MS Paris, BnF, lat. 16211, fol. i verso.
} 
Campanus of Novara's version of the Elements (Book VII, 1). ${ }^{40}$ This version appears in a chained manuscript of the Sorbonne: MS Vatican, Biblioteca Apostolica, Vaticana, Reg. lat. 1261 (fols. 61r-197v). Indeed, this part of the manuscript shows several annotations by Jean. These are explanatory notes or calculations. For example, in the margin of Book X.10-11 Jean gave the definitions of incommensurable lines necessary to understand the eleventh proposition of book $\mathrm{X}^{41}$ The question of incommensurability and commensurability was an important concern for Jean de Murs. He addressed this issue in various works. ${ }^{42} \mathrm{He}$ was also highly interested in another text contained in this manuscript: the anonymous treatise on practical geometry known as Artis cuiuslibet consummatio. ${ }^{43}$

Two other manuscripts from the chained library feature annotations by Jean des Murs dealing with music theory. They respectively contain Jerome of Moravia's theory of music (MS Paris, BnF, lat. 16663), which is the only extant witness to this treatise, and a collection of various musical treatises, some of them related to the Cistercian reformation (MS Paris, BnF, lat. 16662). ${ }^{44}$ Jerome of Moravia's De musica was one of the sources of the Notitia artis

\footnotetext{
${ }^{40}$ The sentence is Unitas est qua unaqueque res est una. See Jean des Murs, Quadripartitum numerorum, ed. Ghislaine l'Huillier (Geneva, 1990), 19-20. See also Hubert L. L. Busard, ed., Campanus of Novara and Euclid's Elements, 2 vols. (Stuttgart, 2005), 1:230.

${ }^{41}$ MS Vatican City, Biblioteca Apostolica Vaticana, Reg. lat. 1261, fol. 130v: 'Linee dicuntur incommensurabiles in longitudine tantum, quando quadrata seu superficies earum se habent in aliqua proportione numerali'.

${ }^{42}$ See Matthieu Husson's contribution in this volume.

${ }^{43}$ MS Vatican, Biblioteca Apostolica Vaticana, Reg. lat. 1261, fols. 292v-96r. See Sephen K. Victor, Practical Geometry in the High Middle Ages: Artis cuiuslibet consummatio and the Pratice de geometrie (Philadelphia, 1979).

${ }^{44}$ On the musical collection of MS Paris, BnF, lat. 16662, see Michel Huglo, 'The Study of Ancient Sources of Music Theory on the Medieval Universities', in Music Theory and its Sources: Antiquity and the Middle Ages, ed. A. Barbera (Notre Dame, 1990), 150-72, at 170.
} 
musice written by Jean des Murs in $1321 .^{45}$ Jean's notes are focused on the chapter dedicated to consonances, and more specifically on folios $37 \mathrm{v}$ and $38 \mathrm{r}$. He added some diagrams and comments to the text. In the second manuscript, Jean seems to focus on Augustine's De musica, including notae and remarks related to metrics.

In parallel with his interest in the chained manuscripts of the Collège, Jean des Murs borrowed several manuscripts from the loan library. MS Paris, BnF, lat. 15461, which comes from Richard de Fournival's library, contains the Liber algorismi de practica arismetice and the Liber Mahameleth, two works on practical arithmetic that played a key role in Jean's own arithmetical writings. ${ }^{46}$ Jean held this manuscript in high esteem, stating that it is highly valued. ${ }^{47}$ The main part of Jean's annotations are contained in the Liber Mahameleth. Evidence for the date of these glosses might be provided by the addition of ' 1324 ' to some computistical tables written by Jean des Murs. ${ }^{48}$ However, there is nothing to preclude that he could have added the year a posteriori. His annotations testify to Jean's thorough reading of both treatises. They are not long glosses, but rather examples added to the margins or developments of calculations, especially for fractions. It seems that Jean sought to simplify the complex calculations contained in the Liber Mahameleth. As he read the Liber algorismi, Jean frequently compared the different computation modes displayed in both works. For example, in the chapter devoted to the subtraction of complex fractions, the Liber

\footnotetext{
${ }^{45}$ Christian Meyer, ed., Jean des Murs: Ecrits sur la musique (Paris, 2000), 31-32, 35-46. The text is edited in: Hieronymus de Moravia, Tractatus de musica, eds. Christian Meyer and Guy Lobrichon (Turnhout, 2012). ${ }^{46}$ Jacques Sesiano, ed., The Liber Mahameleth: A 12th-Century Mathematical Treatise (Cham, 2014). On the Liber algorismi, see also André Allard, 'L'influence des mathématiques arabes dans l'Occident médiéval', in Histoire des sciences arabes, vol. 2, Mathématiques et physique, ed. Roshdi Rashed (Paris, 1997), 199-230.

${ }^{47}$ MS Paris, BnF, lat. 15461, fol. 50v: 'Cui si sciatur non est similis in valore'.

${ }^{48}$ Ibid., fol. 20v.
} 
Mahameleth teaches how to subtract a fraction from other fractions: $\frac{10}{11}-\left(\frac{2}{7}+\frac{3}{10}\right) .{ }^{49}$ The method employed consists in converting the subtrahend into the minuend, that is, converting 2/7 and 3/10 into elevenths. The computation is complex. ${ }^{50}$ Jean noted in the margin melius esset reducere ad idem genus fractionis, that is to reduce the two terms of each fraction in order to abridge the calculation. This is the specific method used in the Liber algorismi ${ }^{51}$

The Liber Mahameleth presented different kinds of problems without giving the solution. Jean located each of them by adding in the margin Nota questiones or Questiones. ${ }^{52}$ For some of these problems, he gave a solution, as is the case on fol. 33r. The question here is: 'Someone asks: what is the amount of which the addition of a fifth, plus two nummi, and half the remainder, plus four nummi makes ten?'53 Jean starts his computation with the demonstration given by the Liber Mahameleth, which concludes that it is like asking what is the amount of which $3 / 5$ is 5 . Jean takes this first proof and multiplies $3 / 5$ by 25 , the result being 15 . Then he multiplies 5 by 25 for the result 125 and divides it by 15 . He obtains $8 \frac{1}{3}$ whose $3 / 5$ makes 5 . He goes even further in offering two other ways to calculate this equation and find the unknown sum: by addition and by subtraction. The annotation hence demonstrates Jean's mastery of algebra and equations as well as his interest in calculations. ${ }^{54}$

\footnotetext{
${ }^{49}$ Ibid., fol. 33rb.

${ }^{50}$ The final result is $\frac{10}{11}-\left(\frac{2}{7}+\frac{3}{10}\right)=\frac{3}{11}+\frac{5}{10} \frac{1}{11}+\frac{4}{7} \frac{1}{10} \frac{1}{11}$.

${ }^{51}$ Jean des Murs, Quadripartitum numerorum, ed. l'Huillier, 47.

${ }^{52}$ For example, Jean wrote 'Nota questiones' at the start of a series of problems, the first one beginning 'Si quis querat: que est pecunia cuius tertia et quinta, et quarta residui, fiunt viginti? (fol. 33ra). Similarly, on fol. 33vb, he noted 'Questiones' next to the problem 'Si quis querat: pecunia de qua demptis tertia eius et duobus nummis et eius quarta minus uno nummo et dimidio residui minus tribus nummis remanet decem, quanta est?'

${ }^{53}$ Sesiano, Liber Mahameleth, 705.

${ }^{54}$ MS Paris, BnF, lat. 15461, fol. 33r: 'Multiplica 5 in se, et sunt 25: cuius $\frac{3}{5}$ sunt 15, duc ergo 5 in 25 et
} 
The fact that he was highly interested in that text is not surprising. In his Quadripartitum numerorum, he studied the four operations as well as the method for extracting cubic and square roots, based on the Liber Mahameleth and Jean de Lignères's Algorismus minutiarum. ${ }^{55}$ This is true especially for the second book where he dedicated eight chapters to fractions and their operations, drawing mainly on the Liber algorismi, the Liber Mahameleth, and the Algorismus minutiarum. MS Paris, BnF, lat. 15461, is a significant witness to Jean's working methods as well as one of the main sources of the Quadripartitum numerorum. In terms of algorism, Jean consulted also MS Paris, BnF, lat. 16202, a book in the loan library containing inter alia the Liber algorismi followed by Exceptiones de libro qui dicitur Gebla Mucabala. ${ }^{56}$

These examples demonstrate that Jean des Murs benefited heavily from both collections of the Collège, that is, the chained library and the loan library. With the notable exceptions of the Liber Mahameleth and Liber algorismi, these annotations usually did not prefigure his own treatises, but instead showcase a scholar who is looking for sources or reflecting on a text. A particularly striking case is his interest in several astrological manuscripts of the college, which could have served as sources for his judgements. The

productum divide per 15 exit $8 \frac{1}{3}$ : cuius $\frac{3}{5}$ sunt 5 . Vel sic: duc 5 in se, et sunt 25 quem divide per 3 et sunt $8 \frac{1}{3}$. Illa est pecunia quesita. Cuius $\frac{3}{5}$ sunt 5 . Aliter ab uno incipiendo: deme $\frac{1}{5} 2$ nummos remanet $\frac{4}{5} 2$ nummis. Diminutis. Cuius medietas est $\frac{2}{5} 1$ nummi diminuto, cui adde 4 nummos et sunt $\frac{2}{5} 3$ nummos. Iunge hoc cum $\frac{1}{5}$ et 2 nummis et exit $\frac{3}{5}$ et 5 nummi, que equantur 10. Oppone ergo 5 contra 10 et remanet $\frac{3}{5}$ equales 5 ergo reduc ad unum integrum, et exit quod una res scilicet summa valet $8 \frac{1}{3}$.'

${ }^{55}$ On the Algorismus minutiarum, see Hubert L. L. Busard, Het rekenen met breuken in de middeleeuwen, in het bijzonder bij Johannes de Lineriis (Brussels, 1968).

${ }^{56}$ On this short text, which deals with solving second-degree equations with the method al-muqābala, see Allard, 'Influence', 220-1. 
Collège de Sorbonne was a place where individuals such as Jean des Murs could pursue their interest and works, within or in parallel with a teaching activity. The intellectual network he was able to build is reflected in his list of book loans, to which I shall turn next.

\section{Jean des Murs's private library}

Few manuscripts can be linked to Jean des Murs as belonging to him and none of them were bequeathed to the Collège. However, the list of book loans in the Escorial MS is a significant witness for the study of Jean des Murs's personal library. Lawrence Gushee studied this source, focusing especially on musical items quoted in the lists of loans. ${ }^{57}$ I will provide a full transcription of these lists in the appendix. The main list was written on fol. 225r, which is a former pastedown, and some other loans are reported on fol. $223 \mathrm{v}$.

Both lists were intended by Jean des Murs as records of loans he granted to friends or acquaintances. The process is largely the same as in the early loan lists we can find on the flyleaves of manuscripts from the Collège de Sorbonne: the name of the borrower is specified and followed by the title of the work borrowed. Once the book was returned to his owner, the item was erased. The list is hence a work in progress ranging from 1321 to 1344 . It also provides other information, for instance concerning the purchase of materials necessary for copying manuscripts: parchment and a ruler. Yet the recipient of these purchases is not Jean des Murs himself, but rather his scribe, as specified by the words scriptor meus habuit. Perhaps Jean employed a professional scribe or a secretary in order to copy manuscripts of his works. ${ }^{58}$ The conscientiousness with which Jean des Murs reported his loans is quite

\footnotetext{
${ }^{57}$ Gushee, ‘Jehan des Murs', 352-71.

${ }^{58}$ A scribe named 'Johannes Anglicus' is mentioned by Jean des Murs on fol. 225r. It is probably the same person as 'scriptor meus'.
} 
surprising given the provenance of the Escorial manuscript. While he was an arts student, Jean borrowed this collection of mathematical and astronomical texts from his fellow student Reginald Daugnon, without ever returning it. ${ }^{59}$

A part of this list is devoted to loans of Jean des Murs's own works. One can assume that his friends wanted to read them and that Jean circulated his works among them. It is not certain that they had the format of a codex rather than some quires poorly bound together. His musical treatises were borrowed by Philippe de Vitry, who received the Musica speculativa on two occasions, and by Dominus D. Legrant (probably Denis Legrant), who had a work with the incipit Princeps philosophorum, which is Jean des Murs's Notitia artis musice. ${ }^{60}$ Jean de Rouen, a monk of the abbey of Bec-Hellouin (where Jean obtained an expectative benefice in 1329), ${ }^{61}$ likewise borrowed two tracts designated by their respective incipits: Omnem doctrinam, which are the first words of the Musica speculativa, and Omnes homines, a treatise identifiable with the work contained in MS Paris, BnF, lat. 7378A (fol. 58r-v), which according to Karen Desmond may have been written by Jean des Murs at the end of the 1320s. ${ }^{62}$ Few musical treatises other than those composed by Jean were loaned, as when Master Alphonse borrowed an unidentified libellum de musicis.

Jean's works were often borrowed several times by different individuals, as was the case with his Arbor Boecii, lent to both Jean de Constance (Johannes de Constantia) and

\footnotetext{
${ }^{59}$ Gushee, 'Jehan des Murs’ 348.

${ }^{60}$ On his musical tracts, see Ulrich Michels, Die Musiktraktate des Johannes de Muris (Wiesbaden, 1970), 1655.

${ }^{61}$ Gushee, 'New sources', 21-22.

${ }^{62}$ An edition of this treatise is in preparation by Karen Desmond. See Desmond, Music and the moderni, 13001500: The ars nova in Theory and Practice (Cambridge, 2018), chapter 3, and Desmond's contribution in this volume.
} 
Robertus Dulcis. ${ }^{63}$ The latter was a fellow of the Sorbonne from 1342. He also borrowed the De arte mensurandi composed by Jean in $1344 .{ }^{64}$ Another example are his canons to the Alfonsine Tables, which appear on the list twice. A Franciscan, here merely identified as 'Frater minorum', took these canons (habet canones meos Alfonsi) and a copy of the Alfonsine Tables. ${ }^{65}$ Below this entry it is noted that a Magister Conradus had a set of Alfonsine Tables. Moreover, at the top of the page it is noted that the Franciscan friar Jacobus de Spinello borrowed Jean's Arithmetica nova, which probably corresponds to his Arithmetica speculativa written in 1324 , or to the first part of the Quadripartitum numerorum. ${ }^{66}$

Furthermore, a certain Master Guillebertus borrowed an astronomical text entitled Ascendens et introitus solis in quartis anni, which may correspond to a set of tables. In addition to this loan, he had the item called Item kalendarium novum meum, which could correspond to Jean's Kalendarium Solis et Lune or the Patefit ${ }^{67}$ Finally, Master Alphonse owned a treatise called De coniunctionibus magnis Jovis et Saturni. Jean dealt with Saturn and Jupiter conjunctions in his astrological judgement of the great conjunction of 1365. However, it is difficult to

\footnotetext{
${ }^{63}$ On the Arbor Boecii see Matthieu Husson, 'Les premiers témoins de l'Arbor Boecii de Jean de Murs: deux contextes distincts pour l'enseignement de l'arithmétique spéculative au XIVe siècle', in Mélanges en l'honneur de Danielle Jacquart (Geneva, forthcoming).

${ }^{64}$ See Hubert L. L. Busard, ed., Johannes de Muris, 'De Arte Mensurandi': A Geometrical Handbook of the Fourteenth Century (Stuttgart, 1998).

${ }^{65}$ Jean des Murs composed these canons in 1339. There is no edition yet. The full text appears in MS Oxford, Hertford College, 4, fols. 140r-47r. See also Poulle, 'John of Murs', 131-32.

${ }^{66}$ Edited in Hubert L. L. Busard, 'Die Arithmetica speculativa des Johannes des Muris', Scientiarum historia 13 (1971), 103-32.

${ }^{67}$ The Patefit is a reworking of the Kalendarium composed after 29 November 1329. See Joël Plassard, 'Projets de réforme du calendrier à Paris au début du XIVe siècle: textes édités et commentés', École Nationale des Chartes: Positions des thèses (Paris, 1975), 175-81, at 177, 181. On the Kalendarium, see also Chabás and Goldstein, 'John of Murs', 411-37.
} 
assert that this generic title refers to this work. ${ }^{68}$ More surprising is Master Bertrand's borrowing of a commentary on the Toledan Tables: Magister Bertrandus habet meum expositorem super tabulas Tholetanas. The possessive pronoun in this loan list is usually attached to works written by Jean des Murs himself, but 'his' Expositio on the Toledan tables might merely refer to a commentary Jean owned. Alternatively, it might be a real work by Jean that is no longer extant.

This list is a significant witness attesting to the dissemination of Jean des Murs's works in his circle of influence in Paris and Normandy. It is also characteristic of his interests in the field of quadrivium. In astronomy, Jean owned a copy of Ptolemy's Almagest, the Almagesti minor, and another collection of astronomical texts containing the Toledan Tables, the De spera, and De computo of John of Sacrobosco as well as a treatise called Astrolabium, which is likely to be Pseudo-Messahallah's De compositione astrolabii, and the Theorica planetarum Gerardi. ${ }^{69}$ The Almagest and this astronomical collection were both borrowed by Dominus D. Legrant. Furthermore, Jean de Constance, who was a master of the University of Paris and Berthaud de Constance's disciple, borrowed a treatise named 'Johannes de Cecilia', which is the Expositio super canones Azarchelis de tabulis Toletanis of John of Sicily. ${ }^{70}$ It is perhaps thanks to Berthaud de Constance, who was a fellow of the Sorbonne from 1331, and then prior of the Collège, that Jean des Murs knew Jean de Constance.

Astrology is well represented in the list of loans. Together with astronomical works, astrological treatises constituted the lion's share of Jean's library. Jean de Constance, for

\footnotetext{
${ }^{68}$ Boudet, 'La papauté', 270-76.

${ }^{69}$ On the Almagesti minor, see the forthcoming edition of Henry Zepeda, The First Latin Treatise on Ptolemy's Astronomy: The Almagesti minor (ca. 1200) (Turnhout, forthcoming).

${ }^{70}$ Fritz S. Pedersen, 'Scriptum Johannis de Sicilia super canones Azarchelis de tabulis Toletanis', 2 pts., Cahiers de l'Institut du Moyen Âge Grec et Latin 51-52 (1986).
} 
example, borrowed an astrological work entitled Libellus dignitatum, which was probably based on the five dignities of the planets. The astrologer Firmin de Beauval, Jean's close collaborator, borrowed several astrological works. The De mansionibus lune, followed by canones, is a treatise related to the twenty-eight lunar mansions used in astrological judgements. Firmin also borrowed al-Kindi's astro-meteorological treatise De mutatione temporum, a work on constellations (ymagines celi), and Pseudo-Ptolemy's De imaginibus super facies signorum, which includes forty-six chapters devoted to the elaboration and use of astrological talismans. ${ }^{71}$ These loans are in line with Firmin's known astrological interests and practice.

In the field of astrology, Guillaume de Navarre asked for a De revolucionibus planetarum, which could correspond to the De revolutionibus annorum mundi of Albumasar or the one written by Messahalla. Master J. de Montargis borrowed the Liber novem iudicum dedicated to astrological interrogations. ${ }^{72}$ An unidentified master owned a book called after its author 'Abraham Evanerie', that is Abraham ibn Ezra. Master Alphonse seems to have borrowed the same work. In his case, the title is given as De principio sapientie, which can be

\footnotetext{
${ }^{71}$ On al-Kindi's De mutatione temporum, see Gerrit Bos and Charles Burnett, eds., Scientific Weather Forecasting in the Middle Ages: The Writings of Al-Kindi (London, 2000). On Pseudo-Ptolemy, De imaginibus, see Jean-Patrice Boudet, 'Un traité de magie astrale arabo-latin: le Liber de imaginibus du Pseudo-Ptolémée’, in Natura, scienze e societa medievali: studi in onore di Agostino Paravicini Bagliani, eds. Claudio Leonardi and Francesco Santi (Florence, 2008), 17-35.

${ }^{72}$ Charles Burnett, 'A Group of Arabic-Latin Translators Working in Northern Spain in the Mid-12th Century', Journal of the Royal Asiatic Society of Great Britain and Ireland 1 (1977), 62-108.
} 
identified as Abraham ibn Ezra's astrological work Principium sapientie or Reshit Hokhma, translated into Latin by Henri Bate (1292) and again by Pietro d'Abano (1293). ${ }^{73}$

Boethius is represented by his De arithmetica lent to Robertus Dulcis and the commented copy of the De musica borrowed by Philippe de Vitry. The latter also borrowed Hugh of Saint Victor's art of reading, that is, the Didascalicon. Jacobus de Spinello borrowed a Perspectiva Philippi, not otherwise identified, which is the only optical work on this list. He also borrowed another treatise entitled Rationes de divisione cum commento, which again remains unidentified.

Among the borrowers one notes Nicolas d'Autrécourt, fellow at the Sorbonne in the 1330s and 1340s. It is probably during a stay at the Collège in the 1330s that Jean met him. Lawrence Gushee argued that the absence of the master title may situate this loan after Nicolas's trial in $1347 .{ }^{74}$ Nicolas d'Autrécourt borrowed Walter Burley's commentary on the Physics. It is difficult to say whether it refers to the commentary on the first six books of the Physics elaborated between 1324 and 1327, the commentary on the seventh and eight books (1334-1337), or the whole treatise. ${ }^{75}$ At any rate, this loan shows that Jean was interested in natural philosophy. This interest was somewhat limited, however, as Walter Burley’s commentary is the only example on this list. No other Aristotelian works are listed, except the Pseudo-Aristotelian Secretum secretorum borrowed by the dean of Évreux.

Medicine is represented by Berard de Gordon's Lilium medicine, a lapidary and herbal borrowed by Jean de Turre, a master of medicine from Paris who taught in Montpellier in

\footnotetext{
${ }^{73}$ On the Introductorium qui dicitur Principium sapientie, see Lynn Thorndike, 'The Latin Translations of the Astrological Tracts of Abraham Avenezra', Isis 35 (1944), 293-302; Renate Smithuis, 'Abraham Ibn Ezra's Astrological Works in Hebrew and Latin: New Discoveries and Exhaustive Listing', Aleph 6 (2006), 239-338.

74 Gushee, 'Jehan des Murs', 354-55.

75 See Rega Wood, 'Walter Burley’s Physics Commentaries', Franciscan Studies 44 (1984), 275-327.
} 
$1335 .{ }^{76}$ Bernard de Gordon's textbook was also borrowed by Adam de la Greve, a clerk of Philippe de Navarre. The Liber de quindecim stellis attributed to Hermes, which deals with talismanic magic, was another work borrowed by Jean de Turre. ${ }^{77}$ Finally, it should be mentioned that Jean was also lending instruments, such as a tin emispherium.

It is likely that this list offers us no more than a sample of Jean's library and should not be mistaken for an overview of his entire collection. But the importance of Alfonsine Tables and canons as well as astrological texts and Jean's own works are notable. More striking perhaps is the high number of astrological texts. The list is a precious document for the history of ideas, showing how works written by a scholar were circulating soon after their writing. It is representative of Jean's interests and in particular of his acquaintances with masters of the Parisian university and Sorbonne, individuals from Normandy or of the Navarrese court, and other collaborators. ${ }^{78}$ Borrowers belonged to different milieus in which Jean des Murs socialized or received patronage. High-ranking churchmen attending the French court and the Papal curia, such as Philippe de Vitry, are part of the list. Jean and Philippe shared the same idea of the Ars nova and may have been in contact with each other in Paris or in Avignon. ${ }^{79}$ Philippe de Vitry's presence on this list is not surprising, as Jean

\footnotetext{
${ }^{76}$ Alberto Alonso Guardo, 'El "Lilium medicine" y el "Tractatus de crisi et de diebus creticis" de Bernardo de Gordonio: estudio comparativo', in Nova et vetera: nuevos horizontes de la Filología Latina, eds. Ana María Aldama Roy, María F. Barrio, and A. Espigares (Madrid, 2002), 435-43.

${ }^{77}$ Paolo Lucentini and Vittoria Perrone, I testi e i codici di Ermete nel Medioevo (Firenze, 2011), 31, 46.

${ }^{78}$ See the list of identified borrowers in the appendix.

${ }^{79}$ A confirmation of Philippe de Vitry's and Jean des Murs's friendly relationship lies in Philip's presence in the list of loans, and in the fact that Jean dedicated his Quadripartitum numerorum (completed the 13 November 1343) to him. Furthermore, Philip was in Avignon in the 1340s, when Jean and Firmin were summoned by Clement VI in 1344. See Andrew Wathey, 'Philippe de Vitry's Books', in Books and Collectors 1200-1700: Essays Presented to Andrew Watson, eds. James P. Carley and Colin Tite (London, 1997), 145-52.
} 
dedicated to him his Quadripartitum numerorum in $1343 .{ }^{80}$ The list demonstrates that Jean kept links with masters of the University of Paris, such as Jean de Constance, or the more controversial Nicolas d'Autrécourt. It also documents the personal contacts he maintained with individuals from Navarre, such as Adam de la Greve or Jean de Navarre, or with the Abbey of Bec-Hellouin (Jean de Rouen). As with Philippe de Vitry, the recurrence of Firmin of Beauval's name confirms the impression that Jean and Firmin were longstanding collaborators and friends.

\section{Jean des Murs's extant manuscripts}

Jean des Murs's uses of manuscripts in the Sorbonne and the part of his personal library described in the loan list constitute precious evidence of a scholar at work, gathering tools and materials for his mathematical activities. However, an equally important testimony is provided by the extant manuscripts formerly in Jean's possession. The Escorial manuscript discussed above was of course one of them, but it is not possible to link any of the loans previously mentioned to known manuscripts. It seems that the works borrowed by Jean's acquaintances were contained in quires rather than proper codices.

Jean never bequeathed his library to his former Collège, and few traces remain of it. As Lawrence Gushee has pointed out, three of the manuscripts owned by Jean des Murs were linked to Julien des Murs, who has been mentioned above. Indeed, Jean may have bequeathed his library to his relative. Several pieces of evidence suggest this link. The second part of MS London, British Library, Royal 12.C.XVII, which is a composite volume of two distinct parts bound together at a later date, includes Jean's and Julien's annotations. Julien's signature is quite characteristic and recognisable, as is his unsteady handwriting with English rotunda

\footnotetext{
${ }^{80}$ Jean des Murs, Quadripartitum numerorum, ed. l'Huillier, 13.
} 
features. He wrote on a former parchment flyleaf an account in Middle French concerning a house sale in the street of the Teste Noire, and annuities to some lords such as Imbert de Lyon. All these affairs were conducted on the behalf of the king of France. On the next leaf, Jean des Murs drew up a circular diagram showing the years of the indictional cycle (from 1344 to 1370$).{ }^{81}$ The same manuscript contains Jean's calendrical-astronomical work known as the Patefit, which is here dedicated to Geoffroy, abbot of Le Bec-Hellouin (1327-1335). Lawrence Gushee suggested that the quality of the text and illumination attests that it was a presentation copy. If so, it never came to Le Bec, or at least returned to Jean des Murs, because he annotated and amended the volume in some places. The Patefit is followed by some additions probably also written by Jean, and the Canones eclipsium of John of Genoa, who was active in Paris in the 1330s. ${ }^{82}$ The manuscript ends with a short excerpt from eclipse canons commonly attributed to John of Saxony. ${ }^{83}$ The volume was probably assembled in its final shape in the 1340 s, certainly after 1344 , which is the date of composition of the anonymous astrological tract Quoniam electiones laudabiles sunt salubres (fols. 212va-

\footnotetext{
${ }^{81}$ MS London, British Library, Royal 12.C.XVII, fol. 145r.

${ }^{82}$ A detailed study of Jean's manuscripts, and especially MS London, British Library, 12.C.XVII, as well as a critical edition of John of Genoa's Canones eclipsium are in preparation.

${ }^{83}$ These eclipse canons are printed in full in José Martínez Gázquez, ed., Traducción castellana anónima de los Cánones de Juan de Sajonia: las tablas de los movimientos de los cuerpos çelestiales del Iluxtrisimo Rey don Alono de Castilla seguidas de su Additio (Murcia, 1989), 95-129. For discussion, see Emmanuel Poulle, Les Tables Alphonsines avec les canons de Jean de Saxe: édition, traduction et commentaire (Paris, 1984), 24-25.
} 
$212 \mathrm{vb}) .{ }^{84}$ Jean also added a small piece of paper on fol. 212 , where he wrote an account of the equal and unequal planetary hours. ${ }^{85}$

The second witness is more a fragment than a volume. It consists of a bifolio inserted in a later English manuscript, now MS London, British Library, Royal 12.D.VI. ${ }^{86}$ This bifolio contains a copy of the Figura inveniendi sinus kardagarum. The text in itself was not copied by Jean des Murs. It would be no more than an ordinary copy, had Jean not annotated the end of his treatise and added a calculation in the upper margin of fol. 70r. The handwriting of the main text may be attributed based on its ductus to Julien des Murs.

Another manuscript to strengthen the hypothesis that Jean des Murs bequeathed his library to his relative is MS Cambridge, University Library, Mm.IV.43, which was evidently in his possession. The whole manuscript was copied in Paris, by different scribes. The last part containing the Astronomia of Ramon Llull is dated to 1298, shortly after Ramon had achieved his work. ${ }^{87}$ The main hands date to the first quarter of the fourteenth century. It opens with a miniature including a master looking at the sky and holding an astrolabe. This volume contains Haly Abenragel's De iudiciis astrorum, Haly Embrani's De electionibus horarum (second book only), the Pseudo-Ptolemaic Centiloquium in Plato of Tivoli's translation, including the commentary attributed to Haly Embrani, the Pseudo-Ptolemaic De cometis, and a compendium of Zael's treatises including the Introductorium, the

\footnotetext{
${ }^{84}$ The same work is contained in MS Nuremberg, Stadtbibliothek, Cent. VI 22, fols. 11ra-12ra, ending: 'Explicit liber de electionibus medicine editus Parisius anno Domini 1344'.

${ }^{85}$ See Gushee, 'New Sources', 21-24. Jean inserted small paper slips mounted by a stub of paper or parchment to MS Paris, BnF, lat. 7380, fols. 37, 38. These pieces are also annotated by him.

${ }^{86}$ MS London, British Library, Royal 12.D.VI, fols. 69v-70r; Gushee, ‘Jehan des Murs’, 364.

${ }^{87}$ José Maria Millas Vallicrosa, 'El “Tractatus novus de astronomia” de Ramón Lull', Studia Lulliana 6 (1962), $257-73$.
} 
Quinquaginta precepta, and the De interrogationibus. ${ }^{88}$ These texts are followed by a Tabula fortune according to the twelve signs and months. A treatise on the twelve zodiacal signs has been added next to al-Kindi's treatise and is of a later hand (end of the fourteenth century). The manuscript ends with Ramon Llull's Astronomia. On the verso of the antepenultimate leaf and on the last leaf there is a copy of Jean des Murs's Figura inveniendi sinus Kardagarum. ${ }^{89}$ This last item constitutes an addition of the second quarter of the fourteenth century.

Internal evidence indicates that this manuscript served as Jean's astrological textbook. Indeed, its 304 folios were foliated by Jean himself and include an autograph table of contents on the verso of the second flyleaf. Jean annotated a large part of the De iudiciis astrorum. These notes consist of basic explanations of Arabic terminology, for instance the term atazir. ${ }^{90}$ A marginal annotation still in the same treatise refers to the year 1330 and the location of the Moon at that time (fol. 179r). Moreover, he quotes Albumasar De magnis coniunctionibus in order to comment on a passage devoted to the fortunate and unfortunate years. ${ }^{91}$ Jean's strong interest in Haly Abenragel's work is evident from the fact that he consulted it not only in the

\footnotetext{
${ }^{88}$ On Pseudo-Ptolemy's Centiloquium and De cometis, see David Juste, 'Pseudo-Ptolemy, Centiloquium', Ptolemaeus Arabus et Latinus. Works, http://ptolemaeus.badw.de/work/24; Juste, 'Pseudo-Ptolemy, De cometis', Ptolemaeus Arabus et Latinus. Works, http://ptolemaeus.badw.de/work/43 [accessed 19 March 2018].

${ }^{89}$ Maximilian Curtze, 'Urkunden zur Geschichte der Trigonometrie im christlichen Mittelalter', Bibliotheca mathematica, $3^{\text {rd }}$ ser., 1 (1900), 321-416, at 413-16.

${ }^{90}$ MS Cambridge, University Library, Mm.IV.43, fol. 84v: 'hic aspicit quod atazir est directio’. On fols. 79v-80v he gave a definition of hyles. Ibid., fol. 95r: 'signa solis: leo, virgo, liber, cancer/ signa lune: aquarius, piscis, aries, taurus'.

${ }^{91}$ Ibid., fol. 202r: 'Coniunctio que significat legem Arabum fuit in Scorpio et hoc dicit Albumasar in fine $2 \mathrm{i}$ libri de magnis coniunctionibus, quorum propheta fuit Machometus post adventum Christi per 621 annos et 95 dies'.
} 
Cambridge manuscript, but also in MS Paris, BnF, lat. 16206. The attention he paid to this text can be linked to his own astrological judgments on great conjunctions. ${ }^{92}$

At the end of the manuscript, following the colophon of Raymond's Astronomia, are several notes in Jean's and Julien de Murs's hands. Jean wrote a note in order to explain the calculation of the revolution of the year. It is followed by three examples for the year 1320 . Julien wrote the dates of birth of Charles V, followed by his signature, and of Philippe II of Burgundy. He made numerous pen trials in the lower margin, writing per regem in a chancery script. As with MS London, British Library, Royal 12.C.XVII, the Cambridge manuscript was brought to England by Julien, who was one of the members of the court of Jean II who followed him into exile in 1356.

The partly autograph manuscript containing the De arte mensurandi, now MS Paris, $\mathrm{BnF}$, lat. 7380, is further proof that Jean bequeathed his library to Julien and that he was keen on keeping neat copies of his works. ${ }^{93}$ It is worth noting that Julien des Murs also annotated part of this manuscript. Moreover, Lawrence Gushee demonstrated that the two ex-libris of this volume are significant for tracking the later owners of Jean's manuscript. It was owned by Nicole Oresme's nephew, Henri Oresme, who subsequently offered it to Henry of Fontanis, a master of arts and student in theology from the diocese of Bayeux. Nicole Oresme was well-acquainted with Jean's Quadripartitum numerorum, because he referred to it in his De proportionibus proportionum. And Julien des Murs might have met Nicole Oresme during his stay in Rouen or when he was the rector of the university of Paris. It is not impossible that Julien offered or bequeathed a part of Jean's collection to Nicole Oresme. ${ }^{94}$

\footnotetext{
${ }^{92}$ See Jean-Patrice Boudet's contribution in the same volume.

${ }^{93}$ See the manuscript description in Victor, 'Johannes de Muris', 389-95.

${ }^{94}$ Gushee, 'Jehan des Murs', 365-70.
} 
Finally, another manuscript that was probably owned or at least consulted by Jean des Murs is the first part of MS Paris, BnF, lat. 7198 (fols. 1-110). This manuscript of the end of the thirteenth century contains calendar tables falsely attributed to Robert Grosseteste, preceded by canons beginning Ad notitiam istius kalendarii primo sciendum. The tables are followed by a short text on the cylinder sundial beginning 'Accepturus horas cum chilindro verte ciotherum' and an anonymous thirteenth-century Algorismus de fractionibus. ${ }^{95}$ The relevant part ends with Pseudo-Messahalla's De compositione astrolabii and the Toledan Tables (with canons $\mathrm{Cb}$ ). Jean wrote a note in the calendar mentioning the solar eclipse of 14 May $1333 .{ }^{96}$ Further evidence is given by the fact that the Algorismus de fractionibus, dedicated to sexagesimal fractions, had been used by him in the second book of the Quadripartitum. ${ }^{97}$ If Jean was not the owner of this manuscript, it is at least another witness to the scope of his reading and his scientific practice.

\section{Conclusion}

If one combines the evidence available it is possible to obtain an overview of Jean des Murs's reading interests, his work, and his intellectual networks. He took advantage of several manuscripts of the Sorbonne, covering different mathematical disciplines. His annotations reveal his diligence in the use and reading of texts. They rarely are long glosses, but

\footnotetext{
${ }^{95}$ On this calendar and the prologue, see Jennifer Moreton, 'Robert Grosseteste and the calendar', in Robert Grosseteste: New Perspectives on his Thought and Scholarship, ed. James McEvoy (Turnhout, 1995), 77-88, at 78-79. The Algorismus de fractionibus begins 'Cum multos de numeris tractatus vidisses'. On manuscripts containing this text, see Lynn Thorndike and Pearl Kibre, A Catalogue of Incipits of Mediaeval Scientific Writings in Latins, rev. ed. (Cambridge, Mass., 1963), col. 320.

${ }^{96}$ MS Paris, BnF, lat. 7198, fol. 3r: 'Hic fuit eclipsis solis in prima pulsatione vesperarum Ebreduni, scilicet anno Domini $\mathrm{M}^{\circ} \mathrm{CCCXXXIII.} \mathrm{Duravit} \mathrm{quasi} \mathrm{per} \mathrm{III} \mathrm{horas'.}$

${ }^{97}$ Jean des Murs, Quadripartitum numerorum, ed. l'Huillier, 36.
} 
nevertheless reveal Jean's attention to methods and definitions. He also sometimes compared one text with another in his notes. Several of his marginal comments may be linked to his own work, as is the case with the Liber Mahameleth and the Quadripartitum numerorum. It is also conspicuous that his readings are mainly focused on quadrivial texts, confirming that Jean des Murs was an astronomer, a mathematician and a music theorist, but also an astrologer. While his prognostications belong to the later stages of his career, the evidence furnished by manuscripts and his list of loans demonstrates that he was already involved in that discipline at earlier stages.

His list of loans reveals that Jean was a well-connected scholar who maintained close links with individuals he met during his career. It also sheds light on the circulation of texts and ideas among scholars. Indeed, it shows that works written by Jean were first read by the author's acquaintances. The loan list and the few extant manuscripts bear witness to only a small part of Jean's library. However, they jointly testify to his quadrivial interests, as he apparently owned very few texts that were not related to a scientific discipline. The fate of his own library is hypothetical, but he probably bequeathed his whole collection of books, including his own works, to Julien des Murs, his relative. In conclusion, Jean des Murs may be considered a real calculator who dedicated himself to the quadrivium and who was always in search of new texts to read and comment on as a source of stimulation for his own work. 
Appendix I: Loan lists in MS El Escorial, Real Biblioteca de San Lorenzo, O.II.10, fols. 223v, $225 v^{98}$

[fol. 223v]

[1] Dominus Dyonisus Legrant/ habet librum .9. iudicum/ Item de [?] / Item algorismum, speram, compotum et tabulas Tholetanas/ Item librum de iudiciis in turpi littera et mala.

[2] Magister Philippus de Vitriaco habet musicam Boecii cum commento/ et Didascalicon Hugonis.

[fol. 225v]

[3] Frater Jacobus de Spinollo perspectiva magistri Philippi. Item primum meum arismetice nove

[4] Magister Philippus de Vitriaco habet meum commentum super musicam.

[5] Magister Bertrandus habet meum expositorem super tabulas Tholetanas. ${ }^{\text {Item arismeticam. }}$

[6] Magister J. de Constantia habet libellum dignitatum et arbori boecii.

[7] Magister R. le Marchant habet didascalicon Hugonis.

${ }^{98}$ I only transcribe borrower and book mentions. 
[8] Frater Jacobus de Spinello habet rationes de divisione cum commento.

[9] Dominus D. Legrant habet tabulas tholetanas et speram, compotum, astrolabium, theoricam planetarum etc.

Item habet summam musice Princeps philosophorum. Item habet Almagestum Ptolomei.

[10] Dominus J. de Rothomago monachus de Becco Helloyni habet tractatus meos de musica Omnem doctrinam. Item Omnes homines etc.

[11] Dominus decanus Ebroicensis habet de secretis secretorum Aristotelis.

[12] Magister Firminus habet de mansionibus lune et canones.

Item ipsem habet Alkindium de pluviis.

[13] Frater minor habet canones meos alfonsi. Item habet tabulas Alfonsi.

[14] Magister Conradus habet tabulas Alfonsi.

[15] Magister J. de Turre habet lilium medicine. Item de celidonia. Item de perlis (?).

Item habet de .15. stellis, lapidibus, herbis secundum Hermetem.

[16] Item magister Firminus habet Alkindi. Item ymagines celi.

Item ymagines ptholomei in almagesto penes magistrum Firminum.

[17] Item Nicolas de Ultricuria habet Galterum super librum phisicorum. 
[18] Item Lilium medicine penes dominum Adam de Gravia.

[19] Item magister Johannes de Constantia habet Johannem de Cecilia.

[20] Item Frater Galterus emisperium de stagno.

[Addition]

[21] Item [?] habet primum psalterum.

[22] Magister Alfonsus habet libellum Evanerie de principio sapientie. [ajout] Item habet librum Albumazar magnum. Item magister Alfonsus habet libbelum de musicis et mansionibus lune. Item folium de coniunctionibus magnis Iovis et Saturni [?] orbis. Reddidit omnia.

[23] Magister Guillebertus habet ascendens et introitus solis in quartis anni. Item kalendarium novum meum.

[24] Dominus J. de Navarra habet almagestum magnum.

[25] [in the left margin] Item magister R. Douchet habet arborem Boecii de arismetica.

[26] Dominus J. de Montargis habet perspectivam Philippi. Item habet librum .9. iudicium. 
[Lower margin]

[27] Item magister Guillebertus de Navarra habet de revolutionibus planetarum, de clavibus, de equitibus (!). Radices novas alfonsi.

[Left margin]

[28] Robertus de Constavilla habet librum dignitatis.

[29] Frater Galtarus habet duo paria ymaginum celestium.

[30] Guillebertus habet Abraham Evanerie.

[31] Egidius de Maurencourt habet librum [?].

[32] Item Robertus Douchet habet geometriam meam.

[33] Dominus J. de Navarra habet arismetice commentum quod feci in papyro de fructibus. Minor almagesti meum. 


\section{Identified Borrowers}

\section{Adam de la Greve (de Gravia)}

He was clerk of Philippe de Navarre since 1337. Perhaps Adam de la Greve is identifiable with Adam de Gravia, who was canon of Chartres in $1345 .{ }^{99}$

\section{Denis Legrant}

Denis was clerk of the chapel of Philippe VI de Valois in 1328, and first chapelain of the king Jean II in 1349. He was appointed bishop of Senlis in 1350 until his death in 1352 . He may be identified as Dionysius Magnus, author of the chace Se ie chans. ${ }^{100}$

\section{Firmin de Beauval}

Firmin was a native of the diocese of Amiens, and later a canon of Amiens Cathedral. On 17 October 1343, Clement VI granted him a benefice sine cura in the diocese of Cambrai. He is the author of the astrometeorological treatise De mutatione aeris composed in 1338 . He collaborated with Jean des Murs on the Tabule permanentes. He was summoned together with Jean by Pope Clement VI to Avignon to work on a calendar reform. This reform did not come about, but he and Jean jointly wrote the Epistola super reformatione antiqui kalendarii addressed to Clement VI in 1345. He also wrote a prognostication on the triple conjunction of $1345 .{ }^{101}$

\footnotetext{
${ }^{99}$ Gushee, 'Jehan des Murs', 358.

${ }^{100}$ See Karl Kügle, 'Le Grant, Denis', in Grove Music Online. Oxford Music Online, Oxford http://www.oxfordmusiconline.com/subscriber/article/grove/music/41517 [accessed 6 March 2018].

${ }^{101}$ See Olga Weijers, Le travail intellectuel à la Faculté des arts de Paris: textes et maitres (ca. 1200-1500), vol. 4 (Turnhout, 2001), 89-90; Jean-Patrice Boudet, Le Recueil des plus célèbres astrologues de Simon de Phares, 2
} 


\section{Jean de Constance}

He can be identified with Johannes Almannus de Constancia, member of the English nation. He obtained the licenciate in arts in 1333 and became a regent master in 1337 . He was Berthaud de Constance's student. Berthaud de Constance was a regent master, member of the English nation, a socius of the Sorbonne since 1331, and also served as prior of the Collège. ${ }^{102}$

\section{Jean de Rouen}

Monk of the abbey of Bec-Hellouin. ${ }^{103}$

\section{Jacques de Spinello}

O.F.M. Author of questions on the Sentences in $1349 .{ }^{104}$

\section{Jean de Turre}

Jourdain de Turre's son. Master of medicine of the University of Paris in 1322. He taught medicine in Montpellier in $1335 .^{105}$

\section{Nicolas d'Autrécourt}

vols. (Paris, 1997-99), 1:511-12.

${ }^{102}$ See William Courtenay, Parisian Scholars in the Early Fourteenth Century: A Social Portrait (Cambridge, 1999), 136, 172.

${ }^{103}$ See the list of loans.

${ }^{104}$ See William Courtenay, Adam Wodeham: An introduction to his life and writings (Leiden, 1978), 137.

${ }^{105}$ See Danielle Jacquart, Dictionnaire biographique des médecins en France, supplément (Genève, 1979), 188. 
Died in 1369. He obtained his master of arts around 1318-1320. He began his teaching in 1326-1327 while he was a regent master of arts. He became a fellow of the Sorbonne from the early 1330 s until the 1340 s. In 1340, he was summoned by Pope Benedict XII to Avignon to respond to an accusation of controversial teaching. His trial started in 1340 and led to his conviction in 1346. Nicolas recanted his theses before 16 May 1346, that is soon after the papal commissions of Clement VI and Cardinal Curti decided that his writings had to be burnt. At the same time, he was declared unworthy of the magisterium. He moved to Metz and became canon, then a dean of the cathedral chapter until his death. ${ }^{106}$

\section{Philippe de Vitry}

Music theorist and agent of Louis de Clermont, duke of Bourbon in 1327, he was acquainted with Jean, duke of Normandy, the future king Jean II. He was bishop of Meaux since 1351 until his death in 1361. He was appointed several times by Louis de Clermont and Jean II to represent them at the Curia in Avignon. He was well-acquainted to Pope Clement VI and dedicated a motet to him in $1342 .{ }^{107}$

\section{Robert Douchet (Robertus Dulcis?)}

Robertus Dulcis or Robert Ledoux was fellow of Sorbonne since 1342. He became a bachelor in theology the 1st of August 1346. Robert asked for a canon benefice at Saint-Michel de Beauvais. He requested to read theology in Chartres. ${ }^{108}$

\footnotetext{
${ }^{106}$ See Zénon Kaluza, Nicolas d'Autrécourt, ami de la vérité (Paris, 1995).

${ }^{107}$ See Margaret Bent and Andrew Wathey, 'Vitry, Philippe de', in Grove Music Online. Oxford Music Online, http://www.oxfordmusiconline.com/subscriber/article/grove/music/29535 [accessed 6 March 2018].

108 See Glorieux, Aux origines, 1:326-27.
} 


\section{Appendix II}

List of Sorbonne manuscripts consulted by Jean des Murs ${ }^{109}$

\section{Manuscripts}

Paris, BnF, n.a.1. 99

Paris, BnF, lat. 15461

Paris, BnF, lat. 16202

Paris, BnF, lat. 16204

Paris, BnF, lat. 16206

Paris, BnF, lat. 16209

Paris, BnF, lat. 16211

Paris, BnF, lat. 16646

\section{Previous Owners}

Sorbonne

Medieval catalogues

Richard de Fournival

?Richard de Fournival

Richard de Fournival

Pierre de Limoges

Richard de Fournival

Philippe, archdeacon of Dunois

Richard de Fournival

\section{Localisation in the Sorbonne}

libraries

Loan library.

Catalogue of 1338

Libri Quadriviales (LVI) no.1

Loan library.

Catalogue of 1338

Libri Quadriviales (LVI) no. 15

Chained.

Analytical catalogue

shelfmark'P.f'

Chained

Analytical catalogue shelfmark

'A.l'

Loan library.

Catalogue of 1338

Libri Quadriviales (LVI) no. 15

Loan library.

Catalogue of 1338

Libri Quadriviales (LVI) no.74

Loan library

Catalogue of 1338

${ }^{109}$ An article detailing Jean's annotations written in the volumes mentioned is in preparation. 
Libri Quadriviales (LVI) no.48

Paris, BnF, lat. 16653

aris, BnF, lat. 16662

Paris, BnF, lat. 16663

Pierre de Limoges

Vatican City, BAV, Reg. lat. 1261 Pierre de Limoges
Pierre de Limoges

Richard de Fournival
Chained

Analytical catalogue shelfmark

'A.b'

Chained

Analytical catalogue shelfmark

'P.c'

Chained

Analytical catalogue shelfmark

'V.g'

Chained

Analytical catalogue shelfmark

'V.k' 